\title{
Inhibitory action of mVOCs from Shewanella algae Sg8 against phytopathogenic fungi and transcriptional elicitation of PR genes in tomato
}

\section{Radhesh Krishnan Subramanian}

T.Stanes and Company Limited

Sengali Ragunath Kumaravel

T.Stanes and Company Limited

Radhakrishnan Srinivasan

T.Stanes and Company Limited

Narayanasamy Prabakaran

T.Stanes and Company Limited

Keerthana Ponni Kandasamy

T.Stanes and Company Limited

Balaji G

T.Stanes and Company Limited

Latha K ( $\boldsymbol{\nabla}$ testinglab@t-stanes.com )

T.Stanes and Company Limited

\section{Research Article}

Keywords: Microbial volatile organic compounds (mVOCs), Pathogenesis related (PR) gene, Phytopathogenic fungi, Shewanella algae, Plant growth promoting Microbe (PGPM)

Posted Date: October 28th, 2022

DOI: https://doi.org/10.21203/rs.3.rs-1309262/v3

License: (a) (1) This work is licensed under a Creative Commons Attribution 4.0 International License. Read Full License 


\section{Abstract}

The analysis of Microbial volatile organic compounds (mVOCs) is an emerging research field with huge impact in the fields of medical and agricultural biotechnology, mVOCs are being considered as imminent eco-friendly alternatives to chemical pesticides and fertilizers in sustainable agriculture. In this study, we characterized the effect of volatiles emitted from Shewanella algae (Sg8) isolated from a marine ecosystem in promoting plant growth, in controlling the activity of Fusarium oxysporum and its antagonistic activity against other phytopathogenic fungus. Sg8 inhibited the growth of four other agronomically important foliar and soil plant pathogens: Botrytis cinerea, Colletotrichum gloeosporioides, Magnoporthae oryzae and Macrophomina sp. The effect of mVOCs produced by the bacterium Sg8, on plant growth were investigated on tomato plants under in vivo conditions. The VOCs emitted from Sg8 up regulated the Thaumatin-like antifungal ( $P R-5)$ gene (9-fold) and Glutamine synthetase (GS) gene (0.96fold) in tomato plants. Sg8 effectively inhibited the growth of $F$. oxysporum and possessed plant growth promoting (PGP) activity. Our results show that Sg8 generates bioactive volatiles that induces the regulation of Pathogenesis related (PR) genes, and stimulates the growth of the plants and also suppresses the growth of other agriculturally important foliar and soil phyto-pathogenic fungus.

\section{Introduction}

VOCs of microbial origin, have a high potential in agriculture in influencing plant health and overcoming the economic loss caused by the pathogens and pests. The mVOCs apart from having biological and ecological roles also have application as markers for phenotyping and differentiation of phylogenetically closely related species of microorganisms. The volatiles are released during the growth of the microbe along with metabolic products and secondary metabolites that are used for protection against antagonists, competitors, or as signaling molecules in cell-to-cell communication (Garbeva and Weisskopf, 2020; Groenhagen et al., 2013; Krishnan et al., 2021; Ryu et al., 2004; Srinivasan et al., 2022; Zhang et al., 2013). These compounds have antifungal, anti-nematicidal, plant growth modulating activities and a few also function as semio-chemicals. In contrast to macromolecules, these low molecular weight molecules are highly volatile and act not only at the site of their production but also due to the high vapor pressure, they are able to traverse rapidly to longer distances and inflict cellular damage in the pests or pathogens.

Numerous in vitro studies have proven that mVOCs contribute specifically by inhibiting the growth and development of several phytopathogenic fungal members of Alternaria (Aldehydes et al., 1994; Chaurasia et al., 2005; Groenhagen et al., 2013; Trivedi et al., 2008; Zhao et al., 2011), Aspergillus (Chaves-López et al., 2015; Gong et al., 2015; Hua et al., 2014; Vespermann et al., 2007), Botrytis (Huang et al., 2011; Li et al., 2012; Parafati et al., 2015; Rouissi et al., 2013; Wang et al., 2013), Penicillium (Rouissi et al., 2013), Rhizoctonia (Fiddaman and Rossall, 1994, 1993; Kai et al., 2007; LIU et al., 2008; Vespermann et al., 2007), Pythium (Chaurasia et al., 2005; Sánchez-Fernández et al., 2016), Sclerotinia (Fernando et al., 2005; Fiddaman and Rossall, 1994, 1993; Giorgio et al., 2015; Vespermann et al., 2007), and Fusarium (Cordero et al., 2014; Minerdi et al., 2009; Tenorio-Salgado et al., 2013; Vespermann et al., 2007; Wang et 
al., 2013; Yuan et al., 2012), and Phytophthora (Sharma et al., 2015; Yap Chin Ann, 2012; Zhao et al., 2011).

Similarly, many have proven that these mVOCs could be replaced as a potent basal supplement to induce systemic resistance (ISR) in plants. Previous studies have shown overexpression of stress responsive genes in plant and improvement in its adaption to various stresses and increase the yield (Li et al., 2014; Shi et al., 2014).

Three of the PR gene families, $P R-1, P R-2$ ( $\beta-1,3$-glucanases), and $P R-5$ (Thaumatin), have been reported to encode proteins that can convey increased resistance to phytopathogenic fungi when over expressed in plants (Alexander et al., 1993; Broglie et al., 1991). These proteins have assorted functions in development, protection against osmotic and cold stress and also antifungal activity. The above reports imply that PR1, 2, and 5 play pivotal roles in multiple stress tolerance and system acquired resistance (SAR).

Here the effect of mVOCs emitted by the marine isolate S. algae strain Sg8 on the growth of agroeconomically important fungal phytopathogens (Fusarium oxysporum) were explored along with the expression/elicitation of PR genes in the leaves of treated tomato plants. The isolate collected from marine resources was identified as S. algae strain - Sg8 (NCBI accession number - MK121204.1) was analyzed for the inhibitory effect of the volatiles produced, followed by evaluation of its antifungal and plant growth promoting (PGP) activity. Based on the literature survey, it can be mentioned that this is the first report on the induction of defense responsive genes (PR genes) and PGP activity by Sg8.

\section{Materials And Methods}

\section{Isolation and Identification}

Sg8, was isolated from the seaweed Sargassum collected from Munaikadu, Mandapam coast, Rameshwaram district of India ( $\left.9^{\circ} 16^{\prime} 32.56^{\prime \prime} \mathrm{N}, 79^{\circ} 07^{\prime} 25.03^{\prime \prime} \mathrm{E}\right)$. The isolated bacteria were routinely cultured on nutrient agar or nutrient broth (Fang et al., 2014) media. The generated VOCs from the bacterial culture were evaluated by inoculating on Zobell Marine Agar (ZMA) plates (Gong et al., 2015). Bacterial cultures were maintained as $40 \%$ glycerol stocks at $-80 \circ \mathrm{C}$ for long-term storage. The identity of the isolate (Sg-8) was confirmed (based on the microscopy, morphological, biochemical and molecular analysis) as $S$. algae (Kandasamy et al., 2020)

\section{Inoculation experiments}

\section{Culture medium and growth conditions:}

The culture (Sg8) was inoculated in Zobell marine broth and incubated at $30^{\circ} \mathrm{C}$ overnight in orbital shaker at $150 \mathrm{rpm}$ and used as a seed inoculum for testing its inhibitory activity against phyto-pathogenic fungi. 
The antagonistic potential of the isolate against fungal phytopathogens mainly Fusarium oxysporum and others such as Botrytis cinerea, Colletotrichum gloeosporioides, Magnoporthae oryzae and Macrophomina phaseolina) were tested by dual-culture technique (Fernando et al., 2005) using Zobal Marine Agar (ZMA) for Sg8. The radial growth of the pathogens in dual culture and control plates was measured after 7 days of incubation at $28 \pm 1{ }^{\circ} \mathrm{C}$. The average growth of the pathogens in presence of the Sg8 strain was compared with that of the pathogens grown in absence of the strains (control) and the percentage of inhibition was determined (Fernando et al., 2005).

\section{Effect of the VOCs produced by Sg8 on the growth of pathogenic fungi by in vitro assay:}

The antagonistic activity of Sg8 against the mycelial growth of phytopathogenic fungi (Fusarium oxysporum, Botrytis cinerea, Colletotrichum gloeosporioides, Magnoporthae oryzae and Macrophomina phaseolina) was tested following the method of Fernando et al (Fernando et al., 2005) by inverse plate assay. Aliquots of the suspension of the $\mathrm{Sg} 8$ isolate $\left(10^{8} \mathrm{cfu} / \mathrm{ml}\right)$ was inoculated on Zobal Marine Agar (ZMA) plates. A disc ( $5 \mathrm{~mm}$ ) of fully grown phyto-pathogenic fungi (7 day old) was placed on the fresh PDA plate. The two petri dishes were sealed with cello tape (ensuring that no air or volatile leakage is occurred), and incubated at $30^{\circ} \mathrm{C}$ for 5 days. Fungal disc inoculated on (PDA) plates were co-cultured on ZMA plates smeared with ZMB medium was used as a control. The inhibition rate was calculated as follows:

Inhibition rate $(\%)=[$ Diameter of control-Diameter of antagonistic treatment $) /$ the diameter of control] $\times$ 100.

\section{Evaluation of the inhibitory effect of mVOC emitted by Sg8 on the growth of Fusarium oxysporum}

Effect of the mVOC emitted by Shewanella Sg8 strain on the growth of Fusarium oxysporum was tested as per the Tahir et al. (2017). Fusarium oxysporum $\left(1.0 \times 10^{6} \mathrm{CFU} / \mathrm{mL}\right)$ was inoculated in double sterilized garden soil. The container with garden soil was placed above the tissue culture jar inoculated with Sg8 $\left(1.0 \times 10^{8} \mathrm{CFU} / \mathrm{mL}\right)$ on ZMA media. The container and the jar were sealed with scotch tape (ensuring no air exchange) and incubated at $28^{\circ} \mathrm{C}$ for 14 days. Un-inoculated experimental setup served as control.

\section{Effect of mVOCs on the growth tomato plants by in vitro lab assay}

Healthy seeds of tomato were surface sterilized and sown aseptically in the double sterilized garden soil, and the experimental set up (as mentioned above) was placed in a climate controlled green house at $28^{\circ} \mathrm{C}$ for 14 days under a photoperiod of $12 \mathrm{~h}$ light/ $12 \mathrm{~h}$ dark. The VOCs produced by Sg 8 were entrapped in a tissue culture bottle fixed with the plant set up. Tomato saplings were exposed to the VOCs produced by the isolate Sg8. Two weeks after exposure to mVOC's, biometric parameters like plant height, root length, girth, fresh and dry weight were recorded. 
Gene expression of metabolic and PR genes (Glutamine synthetase, Citrate synthase, defense responsive genes such as PR1, 2 and 5) was carried out after exposure to the volatile compounds emitted by the isolate Sg8 and was compared with the expression of the genes of untreated plants.

\section{PR genes expression in response to inoculation with Fusarium oxysporum in tomato plants}

A study was carried out to test the direct and indirect antagonistic effect against $F$. oxysporum (FOC) at green house in pot culture. Pot mixture was prepared by mixing garden sand and farm yard manure at 2:1 $(\mathrm{w} / \mathrm{w})$ and was filled $(3 \mathrm{~kg})$ in 15 inch plastic pots followed by inoculation with FOC inoculum ( $20 \%$ of pot weight, $200 \mathrm{~g}$ per pot; two weeks before sowing). FOC inoculum was mass-multiplied on chickpea grains (variety Co 03; highly susceptible to Fusarium wilt, acquired from Farm Aid Service, TNAU, Coimbatore). Inoculum was thoroughly mixed with the pot mixture and the pots were covered with polythene sheets, in order to maintain the moisture in the soil, and left for 15 days for the development of pathogen and to induce disease condition. Two weeks later, the seedlings of tomato (variety Shivam) were transplanted to the pots and treated with respective treatments viz., Sg8 $\left(10^{8} \mathrm{CFU} / \mathrm{mL}\right), \mathrm{SA}$ and Acibenzolar-S-methyl at a concentration of $10 \mathrm{mM}$ (Khiareddine and El-Mohamedy, 2015) and $0.5 \mathrm{mM}$ (Małolepsza, 2006) solutions respectively.

Gene expression (in PR genes) was monitored $0 \mathrm{~h}, 6 \mathrm{~h}, 24 \mathrm{~h}, 48 \mathrm{~h}, 7^{\text {th }}$ day and $14^{\text {th }}$ day after treatment, and was compared with the gene expression in untreated plants. The RNA was extracted using the RNA express reagent according to the manufacturer's protocol. One $\mu \mathrm{g}$ of total RNA was used to synthesize cDNA with cDNA synthesis kit (Hi-cDNA Synthesis Kit) according to manufacturer's instructions. The authenticity of cDNA was confirmed using Nanodrop quantification.. Real Time (RT-PCR) was carried out by using Bio-Rad SYBR Green master mix; $10 \mu$ reaction volume for each sample was prepared in 96-well PCR plate (BioRad) according to the manufacturer's instruction. Subsequently RT PCR was carried out in BioRad Real-Time PCR. Thermal cycling steps consisted of initial denaturation at $95^{\circ} \mathrm{C}$ for $5 \mathrm{~min}, 30$ cycles of $95^{\circ} \mathrm{C}$ for $30 \mathrm{~s}$, for $30 \mathrm{~s}, 72^{\circ} \mathrm{C}$ for $1 \mathrm{~min}$. The melting temperatures for all genes were analyzed using melt curve analysis from $65.0^{\circ} \mathrm{C}$ to $95.0^{\circ} \mathrm{C}$ with an Increment of $0.5^{\circ} \mathrm{C}$ for $0: 05 \mathrm{~min}$. The sigmoid curves, relative normalized gene expression and melt curve were obtained through qPCR. (The primer details are given in Supplementary Table 1)

\section{Results}

\section{Effect of Sg8 against phytopathogenic fungi by dual plate in vitro assay:}

The inhibition of fungal pathogens in dual-culture test showed the efficacy of Sg8 against all tested fungi (60\% to $87 \%$ ). Among the five different pathogens tested maximum growth inhibition and antagonistic effect of Sg8 was observed against Macrophomina phaseolina (88\%) which causes charcoal rot in different plant hosts and Magnoporthae oryzae (77\%) which is a rice blast pathogen (Supplementary Figure 1). Similarly Sg8 showed effect against Botrytis cinerea (causal agent of gray mold), Colletotrichum gloeosporioides (causal agent of bitter rot in variety of crops) and Fusarium oxysporum 
(causal agent of wilt disease in variety of crops). The inhibitory effect observed in dual plate that the isolate could have arrested the growth of the fungal pathogens through nutritive competition or antibiosis or mycoparasitism or due to the cumulative effect.

\section{Effect of Sg8 mVOCs produced by $S g 8$ on the growth of pathogenic fungi by in vitro assay (VOC):}

The inhibitory effect of the mVOCs emitted by Sg8 was against Macrophomina phaseolina (by $87.8 \%$ which causes charcoal rot, collar rot, and stem rot, in deferent plant hosts) and Magnoporthae oryzae (a rice blast pathogen with $76.67 \%$ inhibition) measured after four days of incubation (Figure 1). Fungal growth inhibition was also observed against Botrytis cinerea (73.17\%), a causative for grey mould; Colletotrichum gloeosporioides (67.03\%) causes bitter rot; and Fusarium oxysporum (60\%) which causes wilt diseases in various hosts.

\section{Evaluation of the inhibitory effect of $\mathrm{mVOC}$ by $\mathrm{Sg} 8$ on the growth of Fusarium oxysporum (in vitro assay)}

The growth of $F$. oxysporum was observed to be reduced in the soil treated with Sg8 (Supplementary Table 2). A similar growth was observed in the soil treated with F. oxysporum that was exposed to Sg8 VOCs (Supplementary Table 3). Inhibitory action of Sg8 against mycelial growth of $F$. oxysporum was noted in the experiment wherein mVOCs were allowed to pass through the soil from the bottom of the tissue culture jar (Supplementary Figure 2).

\section{Growth-Promoting Activity of Sg8 VOCs in tomato plants (in vitro assay-in tissue culture jars)}

The plant growth promoting potential of VOCs produced by S. algae Sg8 was examined by growing plants in tissue culture bottles exposed to Sg8 VOCs for 14 days. No visual deleterious effect was observed on the leaves or to the parts of the plants that were directly exposed to the mVOCs throughout the experimental period (Figure 1).

The data revealed a significant enhancement in the growth of tomato seedlings in terms of fresh weight, dry weight, root and shoot length. The observations recorded on plant height (15.45\%), root length (8.47\%), stem girth (40\%), fresh weight (55.26\%), dry weight (52.17\%) showed that there was a significant increase in the above said parameters in the plants that were exposed to Sg8 in comparison to the untreated control (Supplementary Figure3-5).

The biometric parameters of the plants exposed to the volatiles generated by Sg8 were enhanced when compared to the plants grown in an un-inoculated set up (plant height, root length, girth fresh and dry weight).

Induction of metabolic and defense related genes in plants exposed to mVOC's of $S g 8$ (Plate assayLab):

VOCs of SG8 did not elicit significant effect on the expression of GS gene (0.96-fold) though the biomass of the plants exposed to VOC was higher compared to the un-inoculated plants. The expression of the 
defense responsive genes ( $P R-5$ gene) showed a 9-fold enhancement in its expression compared to uninoculated control, whereas the other pathogen related gene $(P R-2)$ was not stimulated significantly ( 0.5fold) in the presence of the pathogen compared to control that did not show any change in the expression of $P R-1$ gene (Supplementary Figure 3-5).

\section{Induction of defense related genes in tomato treated with $\mathrm{Sg} 8$ in the presence of the pathogen inoculated in the soil (Climate controlled Green-house studies).}

The plants treated with Sg8 and standard synthetic substances elicitated PR genes within 48h. The upregulation of the defense responsive genes were observed in the Sg8 treated tomato plants till 14days, which is an indication of its effectiveness in the control of pathogen. Significant elicitation of $P R 1,2$, and 5 was observed in plants treated with Sg8 (soil application), in the presence of the pathogen compared to the control plants (un-inoculated). The genes encoding $P R 1$ was up regulated by 6 -fold, followed by the $P R$ genes (2 and 5) with 7 and 5 -fold respectively. Figure ( 2 and 3 ) shows that both the activity of $\beta-1$, 3glucanase (PR2) and Thaumatin (PR5) genes in the inoculated plants reached its maximum activity at $7^{\text {th }}$ day post inoculation (dpi) as compared to the pathogen and mock-inoculated controls. On the other hand both the synthetic chemicals that are well established elicitors could trigger the PR genes in tomato plants till $14^{\text {th }}$ day (Figure 2 and 3). Thus it is evident that the isolate Sg8 has the potential to stimulate the PR genes in the plants exposed to F. oxysporum more effectively in soil compared to its invitro inhibitory potential.

\section{Discussion}

Bacterial inoculants modulate plant growth, metabolic and defense gene expression and develop through the emission of mVOCs. The impact of VOCs produced by rhizospheric bacteria on plants and their important role in plant-bacterial interactions has been well-documented. The present study reports the growth promoting; antagonistic; and gene elicitation potential of Sg8, through its ability to produce VOCs. The data recorded on the inhibition of fungal pathogens through the production of volatile and nonvolatile metabolites by Sg8, show that it significantly inhibited the growth of all the pathogens tested. Maximum inhibition of mycelia growth of $M$. phaseolina was observed followed by M. oryzae, B. cinerea, Colletotrichum sp., and F. oxysporum. The inhibitory effects observed can be mainly attributed to the antibiosis effect of the volatile metabolites and induction of defense responsive genes in plants. Thus Sg8 can be considered as a promising bio-control agent for control of root-rot/wilt diseases, as it is able to colonize in advance to the pathogens and stimulate PR genes and promote plant growth under biotic stress

The test pathogen $B$. cinerea is a non-specific, necrotrophic pathogen that reportedly cause heavy crop loss due high disease incidence in most vegetable and oil crops (Cowan et al., 2005; Elad et al., 1994; Petrasch et al., 2019; Swartzberg et al., 2008). Invitro evaluation of the mVOC's released from Sg8 showed that the inhibitory effect of the isolate from marine algae was substantial (73\%) and cogitates its evaluation in open field. 
The inhibitory activity of mVOC's released by Sg8 was effective in controlling the growth $(60 \%)$ of $F$. oxysporum, a fungal pathogen, which is a wide spread threat to a variety of economical important crops like cotton, chickpea, banana, melon and tomato (Gawehns et al., 2015; Michielse and Rep, 2009).

The mVOCs of Sg8 showed significant inhibitory effect (67\%), on the phyto pathogen Colletotrichum geosporioides, a causal agent of anthracnose disease in vegetables, fruits, legumes and ornamental plants (Luis Fernando Zepeda-Giraud et al., 2016). Similarly the mVOCs showed a significant effect on the mycelial growth of Magnoporthae oryzae (a causative agent for rice blast) and M. phaseolina (a causative agent of seedling blight, collar rot, stem rot and root rot). Review of the literature show that this is the first report on the inhibitory potential of $S$. algae strain Sg8 against $M$. oryzae (77\%) and $M$. phaseolina (88\%), thus underlining the potential of the strain as a biological input in agriculture. This is also the first study investigating the growth promoting potential of mVOC's of Sg8 and it demonstrates considerable growth modulation effect on tomato seedlings when the bacterium is grown on culture media beneath the plant system.

GS enzyme is responsible for the production of glutamine in the leaf and generally GS activity is lower during fruit development, due to low metabolic activity, high requirement of carbohydrate, sugar and protein demand for the fruit formation. Glutamine, the major transported amino acid, generally increases in the senescing leaves compared to the early phase of the harvest, as the GS that synthesize, glutamine, is transferred to the growing tissues in plants. The expression of leaf GS activity in the leaves of treated and control plants was monitored to assess if the VOCs produced by Sg8 could activate metabolic machinery, through up-regulation of the glutamine synthase. The genes encoding for GS and CS did not show any increased expression in the plants exposed to volatiles emitted by Sg8.

The genes coding for pathogen resistance (1,2 and 5) showed higher levels of expression after 14 days in plants induced with FOC infection. The accumulation of PR RNAs correlates with the synthesis of PR proteins that are commonly observed to escalate in response to pathogen attack by the plant (Van Loon et al., 2006). Reports show accumulation of specific tomato proteins, including PR proteins, with changes in the xylem sap in Fusarium infected plants (Houterman et al., 2007; Rep et al., 2002).

Plants have evolved the ability to systemically defend to pathogens, through SAR and ISR (Berendsen et al., 2015; Radhesh et al., 2020). A set of PR proteins, such as PR1, PR2 and PR5, were identified as the basic characteristic of SAR signaling pathway (Molinari et al., 2014), and PR3, as the marker of ISR signaling pathway (Yu et al., 2018). The marker genes, PR1, PR2 and PR5 induced by validamycin to enhance plant resistance are considered as markers of SAR (Khunnamwong et al., 2020).

Sg8 mVOC-induced defense responses in tomato in terms of the expression of SA dependent marker genes were analysed by qPCR. The expression level of the SA inducible gene $P R-1$ (unknown anti-fungal function), $P R-2$ ( $\beta$-1,3-glucanase) and $P R-5$ (thaumatin-like protein) genes (Cao et al., 1998, 1997; Cao Hui et al., 1994), showed higher expression ( 9.5 fold) of $P R-5$ gene in plants with the application of mVOCs from Sg8 which could induce enhanced disease-resistance. This investigation indicates that the reported 
S. algae strain Sg8 has the potential to control Fusarium wilt disease and promote growth and induce resistance to pathogens in tomato.

One of the first examples demonstrating an inhibitory role for mVOCs against plant pathogens were those produced by Pseudomonas species isolated from soybean and canola, in the inhibition of Sclerotinia sclerotiorum; a fungal pathogen with a broad host range of over 400 plant species (Fernando et al., 2005). Of 23 VOCs identified from Pseudomonas species, six significantly reduced mycelial growth of $S$. sclerotiorum. Similarly, VOC production by two strains of Bacillus endophytes significantly reduced the weight and number of the vegetative, long-term survival structures (sclerotia) of S. sclerotiorum (Hafiz A S Tahir et al., 2017). VOCs from Burkholderia ambifaria and a range of other rhizobacterial isolates (Groenhagen et al., 2013) have also demonstrated the ability to inhibit growth of the ubiquitous soil-borne pathogen Rhizoctonia solani. MVOCs can also display inhibitory activity against bacterial pathogens. Exposure of Clavibacter michiganensis, the causal agent of bacterial ring rot of potato, to VOCs from Bacillus subtilis led to significant inhibition of pathogen growth, with benzaldehyde, nonanal, benzothiazole and acetophenone specifically demonstrating inhibitory activities (Hafiz Abdul Samad Tahir et al., 2017). Bacillus VOCs also inhibited the growth of Xanthomonas oryzae, the causal agent of bacterial leaf blight of rice, with decyl alcohol and 3,5,5-trimethylhexanol specifically inhibiting pathogen growth (Fernando et al., 2005; Srinivasan et al., 2022, 2017).

Exposing plants to mVOCs result in a significant modulation of plant metabolomics, physiology, and transcriptional status, which confirms that plants have the ability to perceive and respond to microbial volatile compounds (Fincheira and Quiroz, 2018; Gong et al., 2015; Hafiz Abdul Samad Tahir et al., 2017). These studies clearly demonstrate the need for implementation of mVOCs application in Agriculture taking advantage of the multiple functions exhibited such as increase in pathogen resistance, protection against herbivores; enhancement in plant growth and control of disease and pests of plants. The application of mVOCs as plant defense and growth modulators is yet to be established, as out of the 10,000 microbial species described the mVOCs released by 400 bacteria and fungi have been described in the literature (Lemfack et al., 2014).

\section{Conclusions}

Microbial VOCs are intriguingly complex and dynamic and understanding their ecology and evolution is the key to bioprospecting suitable tools for crop protection and production for sustainable agriculture perspective. Application of the Sg8 to tomato plants primed the expression of genes encoding for basic PR-proteins; nitrogen and carbon metabolism and inhibited the growth of plant pathogens, supporting the significance of VOCs that it can trigger growth and defense response similar to ISR. The antagonistic and PGPR activity of Sg8 and the effect of the emitted VOCs will be further studied in open field conditions to validate the results obtained in vitro conditions and to assess its application as a microbial biostimulant or as biocontrol agent and develop it as a cost effective, eco-friendly and sustainable tool for crop protection. 


\section{Declarations}

\section{Ethics approval and consent to participate}

Not applicable

Consent for publication

Not applicable

Availability of data and material

S. algae Sg8 (NCBI accession number - MF143074).

S. algae Sg8 (NCBI accession number - MK121204.1).

\section{Competing interests}

The author(s) declare that there are no conflicts of interest

\section{Funding information}

The authors are thankful to the management of T. Stanes and Company Limited. Coimbatore-18 and BIRAC [Sanction No. BT/SBIRI/1394/31/16] for funding the research.

\section{Authors' contributions}




\begin{tabular}{|c|c|c|}
\hline Contributor Role & Author name & Role Definition \\
\hline \multirow[t]{2}{*}{ Conceptualization } & $\begin{array}{l}\text { Radhesh } \\
\text { Krishnan S }\end{array}$ & \multirow[t]{2}{*}{$\begin{array}{l}\text { Ideas; formulation or evolution of overarching research goals } \\
\text { and aims. }\end{array}$} \\
\hline & Latha K & \\
\hline Methodology & $\begin{array}{l}\text { Radhesh } \\
\text { Krishnan S } \\
\text { Sengali } \\
\text { Ragunath K } \\
\text { Latha K }\end{array}$ & Development or design of methodology; creation of models. \\
\hline Software & $\begin{array}{l}\text { Radhesh } \\
\text { Krishnan S }\end{array}$ & In-silico analysis, molecular confirmation of the organisms, \\
\hline \multirow[t]{2}{*}{ Validation } & $\begin{array}{l}\text { Radhesh } \\
\text { Krishnan S }\end{array}$ & \multirow[t]{2}{*}{$\begin{array}{l}\text { Verification, whether as a part of the activity or separate, of the } \\
\text { overall replication/reproducibility of results/experiments and } \\
\text { other research outputs. }\end{array}$} \\
\hline & Latha K & \\
\hline \multirow[t]{2}{*}{ Formal Analysis } & $\begin{array}{l}\text { Radhesh } \\
\text { Krishnan S }\end{array}$ & \multirow[t]{2}{*}{$\begin{array}{l}\text { Application of statistical, mathematical, computational, or other } \\
\text { formal techniques to analyze or synthesis of study data. }\end{array}$} \\
\hline & $\begin{array}{l}\text { Prabhakaran } \\
\mathrm{N} \\
\text { Latha K }\end{array}$ & \\
\hline \multirow[t]{2}{*}{ Investigation } & $\begin{array}{l}\text { Radhesh } \\
\text { Krishnan S } \\
\text { Srinivasan } \\
\text { R } \\
\text { Sengali } \\
\text { Ragunath K }\end{array}$ & \multirow[t]{2}{*}{$\begin{array}{l}\text { Conducting a research and investigation process, specifically } \\
\text { performing the experiments, or data/evidence collection. }\end{array}$} \\
\hline & Latha $\mathrm{K}$ & \\
\hline
\end{tabular}

\section{Acknowledgements}

The authors are thankful to Dr. V. Karuppaih - Former senior scientist T. Stanes and company limited for collection of the seaweed. Dr. Anantharaman and team - Center of advanced study in marine biology (CACBB), Annamalai University, Chidambaram, Tamil Nadu for association in seaweed collection and identification.

\section{References}

1. Aldehydes, A., Andersen, R. a, Hamilton-kemp, J.T.R., Hildebrand, D.F., Mccracken, C.T., Collins, R.W., Fleming, P.D., 1994. Structure-Antifungal Activity Relationships among Volatile c. Test 1563-1568.

2. Alexander, D., Goodman, R.M., Gut-Rella, M., Glascock, C., Weymann, K., Friedrich, L., Maddox, D., AhlGoy, P., Luntz, T., Ward, E., Ryals, J., 1993. Increased tolerance to two oomycete pathogens in 
transgenic tobacco expressing pathogenesis-related protein 1a. Proc. Natl. Acad. Sci. U. S. A. 90, 7327-7331. https://doi.org/10.1073/pnas.90.15.7327

3. Berendsen, R.L., van Verk, M.C., Stringlis, I.A., Zamioudis, C., Tommassen, J., Pieterse, C.M.J., Bakker, P.A.H.M., 2015. Unearthing the genomes of plant-beneficial Pseudomonas model strains WCS358, WCS374 and WCS417. BMC Genomics 16, 1-23. https://doi.org/10.1186/s12864-015-1632-z

4. Broglie, K., Chet, I., Holliday, M., Cressman, R., Biddle, P., Knowlton, S., Mauvais, C.J., Broglic, R., 1991. Transgenic plants with enhanced resistance to fungal pathogen. Rhizoctonaia solani Sci. 254 SRC-, 1194-1197.

5. Cao, H., Glazebrook, J., Clarke, J.D., Volko, S., Dong, X., 1997. The Arabidopsis NPR1 gene that controls systemic acquired resistance encodes a novel protein containing ankyrin repeats. Cell 88, 57-63. https://doi.org/10.1016/S0092-8674(00)81858-9

6. Cao, H., Li, X., Dong, X., 1998. Generation of broad-spectrum disease resistance by everexpression of an essential regulatory gene in systemic acquired resistance. Proc. Natl. Acad. Sci. U. S. A. 95, 65316536. https://doi.org/10.1073/pnas.95.11.6531

7. Cao Hui, Bowling, S.A., Gordon, A.S., Dong Xinnian, 1994. Characterization of an Arabidopsis mutant that is nonresponsive to inducers of systemic acquired resistance. Plant Cell 6, 1583-1592. https://doi.org/10.1105/tpc.6.11.1583

8. Chaurasia, B., Pandey, A., Palni, L.M.S., Trivedi, P., Kumar, B., Colvin, N., 2005. Diffusible and volatile compounds produced by an antagonistic Bacillus subtilis strain cause structural deformations in pathogenic fungi in vitro. Microbiol. Res. 160, 75-81. https://doi.org/10.1016/j.micres.2004.09.013

9. Chaves-López, C., Serio, A., Gianotti, A., Sacchetti, G., Ndagijimana, M., Ciccarone, C., Stellarini, A., Corsetti, A., Paparella, A., 2015. Diversity of food-borne Bacillus volatile compounds and influence on fungal growth. J. Appl. Microbiol. 119, 487-499. https://doi.org/10.1111/jam.12847

10. Cordero, P., Príncipe, A., Jofré, E., Mori, G., Fischer, S., 2014. Inhibition of the phytopathogenic fungus Fusarium proliferatum by volatile compounds produced by Pseudomonas. Arch. Microbiol. 196, 803-809. https://doi.org/10.1007/s00203-014-1019-6

11. Cowan, A.K., Freeman, M., Björkman, P.O., Nicander, B., Sitbon, F., Tillberg, E., 2005. Effects of senescence-induced alteration in cytokinin metabolism on source-sink relationships and ontogenic and stress-induced transitions in tobacco. Planta 221, 801-814. https:// doi.org/10.1007/s00425005-1489-5

12. Elad, Y., Kohl, J., Fokkema, N.J., 1994. Control of infection and sporulation of Botrytis cinerea on bean and tomato by saprophytic yeasts. Phytopathology 84, 1193-1200. https://doi.org/10.1094/phyto-84-1193

13. Fang, X., Zhang, M., Tang, Q., Wang, Y., Zhang, X., 2014. Inhibitory effect of Xenorhabdus nematophila TB on plant pathogens Phytophthora capsici and Botrytis cinerea in vitro and in planta. Sci. Rep. 4, 1-7. https://doi.org/10.1038/srep04300

14. Fernando, W.G.D., Ramarathnam, R., Krishnamoorthy, A.S., Savchuk, S.C., 2005. Identification and use of potential bacterial organic antifungal volatiles in biocontrol. Soil Biol. Biochem. 37, 955-964. 
https://doi.org/10.1016/j.soilbio.2004.10.021

15. Fiddaman, P.J., Rossall, S., 1994. Effect of substrate on the production of antifungal volatiles from Bacillus subtilis. J. Appl. Bacteriol. 76, 395-405. https://doi.org/10.1111/j.13652672.1994.tb01646.x

16. Fiddaman, P.J., Rossall, S., 1993. The production of antifungal volatiles by Bacillus subtilis. J. Appl. Bacteriol. 74, 119-126. https://doi.org/10.1111/j.1365-2672.1993.tb03004.x

17. Fincheira, P., Quiroz, A., 2018. Microbial volatiles as plant growth inducers. Microbiol. Res. 208, 6375. https://doi.org/10.1016/j.micres.2018.01.002

18. Garbeva, P., Weisskopf, L., 2020. Airborne medicine: bacterial volatiles and their influence on plant health. New Phytol. 226, 32-43. https://doi.org/10.1111/nph.16282

19. Gawehns, F., Ma, L., Bruning, O., Houterman, P.M., Boeren, S., Cornelissen, B.J.C., Rep, M., Takken, F.L.W., 2015. The effector repertoire of Fusarium oxysporum determines the tomato xylem proteome composition following infection. Front. Plant Sci. 6, 1-17. https://doi.org/10.3389/fpls.2015.00967

20. Giorgio, A., De Stradis, A., Lo Cantore, P., lacobellis, N.S., 2015. Biocide effects of volatile organic compounds produced by potential biocontrol rhizobacteria on Sclerotinia sclerotiorum. Front. Microbiol. 6, 1-13. https://doi.org/10.3389/fmicb.2015.01056

21. Gong, A.D., Li, H.P., Shen, L., Zhang, J.B., Wu, A.B., He, W.J., Yuan, Q.S., He, J. De, Liao, Y.C., 2015. The Shewanella algae strain YM8 produces volatiles with strong inhibition activity against Aspergillus pathogens and aflatoxins. Front. Microbiol. 6, 1-12. https://doi.org/10.3389/fmicb.2015.01091

22. Groenhagen, U., Baumgartner, R., Bailly, A., Gardiner, A., Eberl, L., Schulz, S., Weisskopf, L., 2013. Production of Bioactive Volatiles by Different Burkholderia ambifaria Strains. J. Chem. Ecol. 39, 892-906. https://doi.org/10.1007/s10886-013-0315-y

23. Houterman, P.M., Speijer, D., Dekker, H.L., De Koster, C.G., Cornelissen, B.J.C., Rep, M., 2007. The mixed xylem sap proteome of Fusarium oxysporum-infected tomato plants: Short communication. Mol. Plant Pathol. 8, 215-221. https://doi.org/10.1111/j.1364-3703.2007.00384.x

24. Hua, S.S.T., Beck, J.J., Sarreal, S.B.L., Gee, W., 2014. The major volatile compound 2-phenylethanol from the biocontrol yeast, Pichia anomala, inhibits growth and expression of aflatoxin biosynthetic genes of Aspergillus flavus. Mycotoxin Res. 30, 71-78. https://doi.org/10.1007/s12550-014-0189-z

25. Huang, R., Li, G.Q., Zhang, J., Yang, L., Che, H.J., Jiang, D.H., Huang, H.C., 2011. Control of postharvest Botrytis fruit rot of strawberry by volatile organic compounds of Candida intermedia. Phytopathology 101, 859-869. https://doi.org/10.1094/PHYT0-09-10-0255

26. Kai, M., Effmert, U., Berg, G., Piechulla, B., 2007. Volatiles of bacterial antagonists inhibit mycelial growth of the plant pathogen Rhizoctonia solani. Arch. Microbiol. 187, 351-360. https://doi.org/10.1007/s00203-006-0199-0

27. Kandasamy, K.P., Subramanian, R.K., Srinivasan, R., Ragunath, S., Balaji, G., Gracy, M., Latha, K., 2020. Shewanella algae and Microbulbifer elongatus from marine macro-algae - isolation and characterization of agar-hydrolysing bacteria. Access Microbiol. 2, 1-6. https://doi.org/10.1099/acmi.0.000170 
28. Khiareddine, H.J., El-Mohamedy, R.S., 2015. Variation in Chitosan and Salicylic Acid Efficacy Towards Soil-borne and Air-borne Fungi and Their Suppressive Effect of Tomato Wilt Severity. J. Plant Pathol. Microbiol. 6. https://doi.org/10.4172/2157-7471.1000325

29. Khunnamwong, P., Lertwattanasakul, N., Jindamorakot, S., Suwannarach, N., Matsui, K., Limtong, S., 2020. Evaluation of antagonistic activity and mechanisms of endophytic yeasts against pathogenic fungi causing economic crop diseases. Folia Microbiol. (Praha). 65, 573-590. https://doi.org/10.1007/s12223-019-00764-6

30. Krishnan, S.R., Prabhakaran, N., Ragunath, K.S., Srinivasan, R., Ponni, K.K., Balaji, G., Gracy, M., Brindha, C., Narayanan, L., Latha, K., ARITONANG, C.N., 2021. Unearthing the genes of plantbeneficial marine yeast - Wickerhamomyces anomalus strain MSD1. Int. J. Innov. Res. Sci. Technol. 10, 12492-12510. https://doi.org/10.15680/IJIRSET.2021.1009031

31. Lemfack, M.C., Nickel, J., Dunkel, M., Preissner, R., Piechulla, B., 2014. MVOC: A database of microbial volatiles. Nucleic Acids Res. 42. https://doi.org/10.1093/nar/gkt1250

32. Li, J. Bin, Luan, Y.S., Yin, Y.L., 2014. SpMYB overexpression in tobacco plants leads to altered abiotic and biotic stress responses. Gene 547, 145-151. https://doi.org/10.1016/j.gene.2014.06.049

33. Li, Q., Ning, P., Zheng, L., Huang, J., Li, G., Hsiang, T., 2012. Effects of volatile substances of Streptomyces globisporus JK-1 on control of Botrytis cinerea on tomato fruit. Biol. Control 61, 113120. https://doi.org/10.1016/j.biocontrol.2011.10.014

34. LIU, W. wei, MU, W., ZHU, B. yu, DU, Y. chen, LIU, F., 2008. Antagonistic Activities of Volatiles from Four Strains of Bacillus spp. and Paenibacillus spp. Against Soil-Borne Plant Pathogens. Agric. Sci. China 7, 1104-1114. https://doi.org/10.1016/S1671-2927(08)60153-4

35. Luis Fernando Zepeda-Giraud, Dario Rafael Olicón-Hernandez, Cinthya Martínez-López, Guadalupe Guerra-Sánchez, 2016. Study of the Action Mode of Wickerhamomyces anomalus against Colletotrichum gloeosporioides. J. Agric. Sci. Technol. B 6, 341-349. https://doi.org/10.17265/21616264/2016.05.008

36. Małolepsza, U., 2006. Induction of disease resistance by acibenzolar-S-methyl and ohydroxyethylorutin against Botrytis cinerea in tomato plants. Crop Prot. 25, 956-962. https://doi.org/10.1016/j.cropro.2005.12.009

37. Michielse, C.B., Rep, M., 2009. Pathogen profile update: Fusarium oxysporum. Mol. Plant Pathol. 10, 311-324. https://doi.org/10.1111/j.1364-3703.2009.00538.x

38. Minerdi, D., Bossi, S., Gullino, M.L., Garibaldi, A., 2009. Volatile organic compounds: A potential direct long-distance mechanism for antagonistic action of Fusarium oxysporum strain MSA 35. Environ. Microbiol. 11, 844-854. https://doi.org/10.1111/j.1462-2920.2008.01805.x

39. Molinari, S., Fanelli, E., Leonetti, P., 2014. Expression of tomato salicylic acid (SA)-responsive pathogenesis-related genes in Mi-1-mediated and SA-induced resistance to root-knot nematodes. Mol. Plant Pathol. 15, 255-264. https://doi.org/10.1111/mpp.12085

40. Parafati, L., Vitale, A., Restuccia, C., Cirvilleri, G., 2015. Biocontrol ability and action mechanism of food-isolated yeast strains against Botrytis cinerea causing post-harvest bunch rot of table grape. 
Food Microbiol. 47, 85-92. https://doi.org/10.1016/j.fm.2014.11.013

41. Petrasch, S., Silva, C.J., Mesquida-Pesci, S.D., Gallegos, K., van den Abeele, C., Papin, V., FernandezAcero, F.J., Knapp, S.J., Blanco-Ulate, B., 2019. Infection strategies deployed by Botrytis cinerea, Fusarium acuminatum, and Rhizopus stolonifer as a function of tomato fruit ripening stage. Front. Plant Sci. 10. https://doi.org/10.3389/fpls.2019.00223

42. Radhesh, K.S., N, P., Sengali, R.K., R, S., Keerthana, P.K., G, B., M, G., C, B., Lakshmi, N., K, L., 2020. Unearthing the genes of plant-beneficial marine yeast - Wickerhamomyces anomalus strain MSD1. bioRxiv 21, 2020.12.22.424010. https://doi.org/10.1101/2020.12.22.424010

43. Rep, M., Dekker, H.L., Vossen, J.H., De Boer, A.D., Houterman, P.M., Speijer, D., Back, J.W., De Koster, C.G., Cornelissen, B.J.C., 2002. Mass spectrometric identification of isoforms of PR proteins in xylem sap of fungus-infected tomato. Plant Physiol. 130, 904-917. https://doi.org/10.1104/pp.007427

44. Rouissi, W., Ugolini, L., Martini, C., Lazzeri, L., Mari, M., 2013. Control of postharvest fungal pathogens by antifungal compounds from penicillium expansum. J. Food Prot. 76, 1879-1886. https://doi.org/10.4315/0362-028X.JFP-13-072

45. Ryu, C.M., Farag, M.A., Hu, C.H., Reddy, M.S., Kloepper, J.W., Paré, P.W., 2004. Bacterial volatiles induce systemic resistance in Arabidopsis. Plant Physiol. 134, 1017-1026. https://doi.org/10.1104/pp.103.026583

46. Sánchez-Fernández, R.E., Diaz, D., Duarte, G., Lappe-Oliveras, P., Sánchez, S., Macías-Rubalcava, M.L., 2016. Antifungal Volatile Organic Compounds from the Endophyte Nodulisporium sp. Strain GS4d2II1a: a Qualitative Change in the Intraspecific and Interspecific Interactions with Pythium aphanidermatum. Microb. Ecol. 71, 347-364. https://doi.org/10.1007/s00248-015-0679-3

47. Sharma, R., Chauhan, A., Shirkot, C.K., 2015. Characterization of plant growth promoting Bacillus strains and their potential as crop protectants against Phytophthora capsici in tomato. Biol. Agric. Hortic. 31, 230-244. https://doi.org/10.1080/01448765.2015.1009860

48. Shi, W., Hao, L., Li, J., Liu, D., Guo, X., Li, H., 2014. The Gossypium hirsutum WRKY gene GhWRKY39-1 promotes pathogen infection defense responses and mediates salt stress tolerance in transgenic Nicotiana benthamiana. Plant Cell Rep. 33, 483-498. https://doi.org/10.1007/s00299-013-1548-5

49. Srinivasan, R., Krishnan, S.R., Ragunath, K.S., Ponni, K.K., Balaji, G., Prabhakaran, N., Chelliappan, B., Narayanan, R.L., Gracy, M., Latha, K., 2022. Prospects of utilizing a multifarious yeast (MSD1), isolated from South Indian coast as an Agricultural input. Biocatal. Agric. Biotechnol. 39, 102232. https://doi.org/10.1016/j.bcab.2021.102232

50. Srinivasan, R., Ragunath, K., Karuppiah, V., Krishnan, S., Gracy, M., Latha, K., Anantharaman, P., 2017. Isolation and screening of seaweed associated microbes for development of marine based Agri inputs. Seaweed Res. Util. 39, 8.

51. Swartzberg, D., Kirshner, B., Rav-David, D., Elad, Y., Granot, D., 2008. Botrytis cinerea induces senescence and is inhibited by autoregulated expression of the IPT gene. Eur. J. Plant Pathol. 120, 289-297. https://doi.org/10.1007/s10658-007-9217-6 
52. Tahir, Hafiz A S, Gu, Q., Wu, H., Raza, W., Hanif, A., Wu, L., Colman, M. V, Gao, X., 2017. Plant Growth Promotion by Volatile Organic Compounds Produced by Bacillus subtilis SYST2. Front. Microbiol. 8, 171. https://doi.org/10.3389/fmicb.2017.00171

53. Tahir, Hafiz Abdul Samad, Gu, Q., Wu, H., Raza, W., Safdar, A., Huang, Z., Rajer, F.U., Gao, X., 2017. Effect of volatile compounds produced by Ralstonia solanacearum on plant growth promoting and systemic resistance inducing potential of Bacillus volatiles. BMC Plant Biol. 17, 1-16. https://doi.org/10.1186/s12870-017-1083-6

54. Tenorio-Salgado, S., Tinoco, R., Vazquez-Duhalt, R., Caballero-Mellado, J., Perez-Rueda, E., 2013. Identification of volatile compounds produced by the bacterium Burkholderia tropica that inhibit the growth of fungal pathogens. Bioengineered 4, 236-243. https://doi.org/10.4161/bioe.23808

55. Trivedi, P., Pandey, A., Palni, L.M.S., 2008. In vitro evaluation of antagonistic properties of Pseudomonas corrugata. Microbiol. Res. 163, 329-336.

https://doi.org/10.1016/j.micres.2006.06.007

56. Van Loon, L.C., Rep, M., Pieterse, C.M.J., 2006. Significance of inducible defense-related proteins in infected plants. Annu. Rev. Phytopathol. 44, 135-162.

https://doi.org/10.1146/annurev.phyto.44.070505.143425

57. Vespermann, A., Kai, M., Piechulla, B., 2007. Rhizobacterial volatiles affect the growth of fungi and Arabidopsis thaliana. Appl. Environ. Microbiol. 73, 5639-5641. https://doi.org/10.1128/AEM.0107807

58. Wang, Z., Wang, C., Li, F., Li, Z., Chen, M., Wang, Y., Qiao, X., Zhang, H., 2013. Fumigant activity of volatiles from Streptomyces alboflavus TD-1 against Fusarium moniliforme Sheldon. J. Microbiol. 51, 477-483. https://doi.org/10.1007/s12275-013-2586-y

59. Yap Chin Ann, 2012. Rhizobacteria of pepper (Piper nigrum) and their antifungal activities. African J. Microbiol. Res. 6, 4185-4193. https://doi.org/10.5897/ajmr12.583

60. Yu, Z., Yang, G., Liu, X., Wang, Y., Zhuang, L., Zhou, S., 2018. Complete genome sequence of the nitrogen-fixing bacterium Azospirillum humicireducens type strain SgZ-5T. Stand. Genomic Sci. 13, 1-9. https://doi.org/10.1186/s40793-018-0322-2

61. Yuan, J., Raza, W., Shen, Q., Huang, Q., 2012. Antifungal activity of bacillus amyloliquefaciens NJN-6 volatile compounds against Fusarium oxysporum f. sp. cubense. Appl. Environ. Microbiol. 78, 59425944. https://doi.org/10.1128/AEM.01357-12

62. Zhang, X., Li, B., Wang, Y., Guo, Q., Lu, X., Li, S., Ma, P., 2013. Lipopeptides, a novel protein, and volatile compounds contribute to the antifungal activity of the biocontrol agent Bacillus atrophaeus CAB-1. Appl. Microbiol. Biotechnol. 97, 9525-9534. https://doi.org/10.1007/s00253-013-5198-x

63. Zhao, L. jing, Yang, X. nan, Li, X. ying, Mu, W., Liu, F., 2011. Antifungal, Insecticidal and Herbicidal Properties of Volatile Components from Paenibacillus polymyxa Strain BMP-11. Agric. Sci. China 10, 728-736. https://doi.org/10.1016/S1671-2927(11)60056-4

\section{Figures}




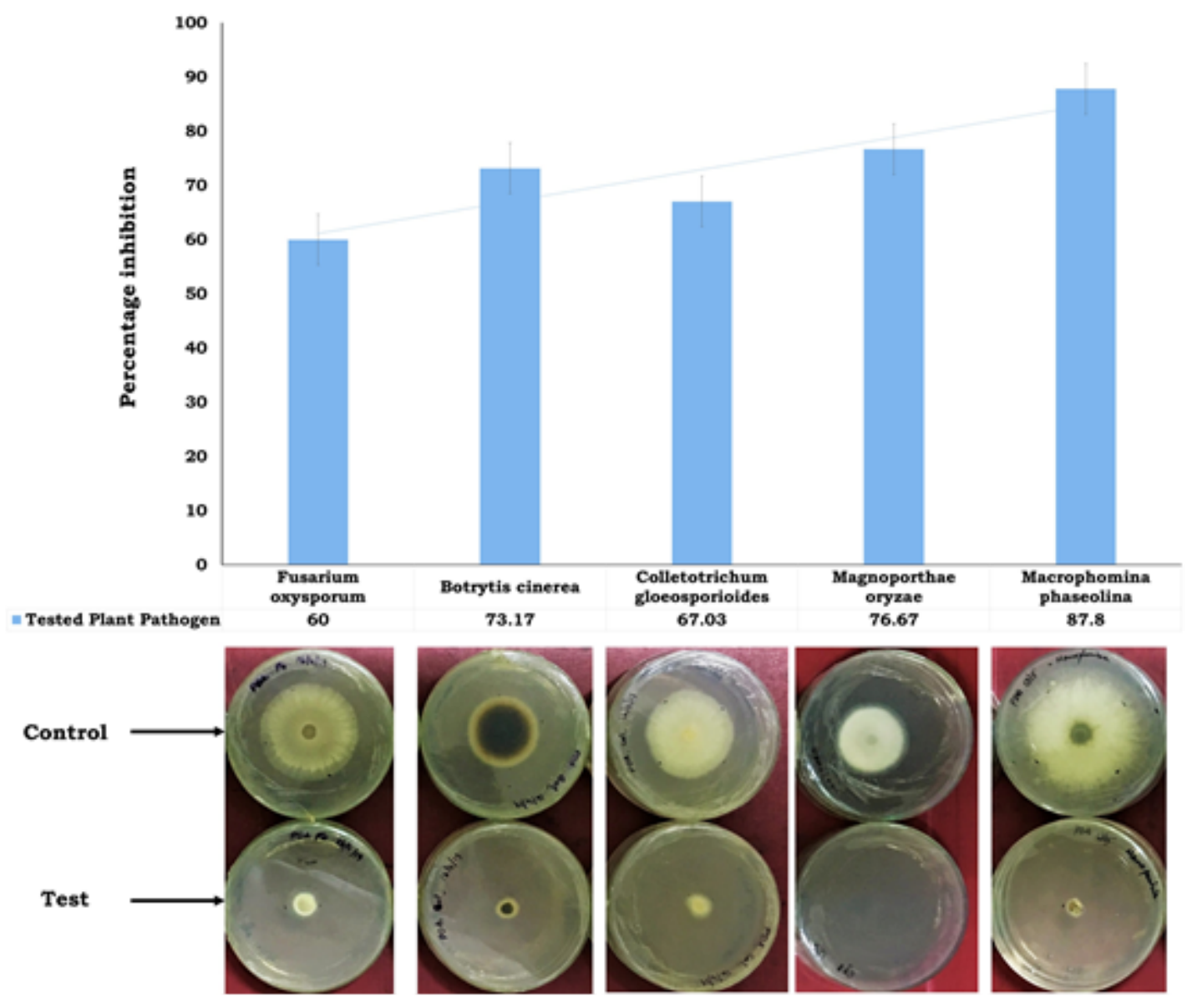

Figure 1

Paired plate Assay for evaluating the effect of the volatile Compounds (VCs) of Sg8 on phytopathogenic fungi

Effect of the volatile organic compounds produced by $S$. algae $(\mathrm{Sg} 8)$ on the growth of pathogenic fungi. 

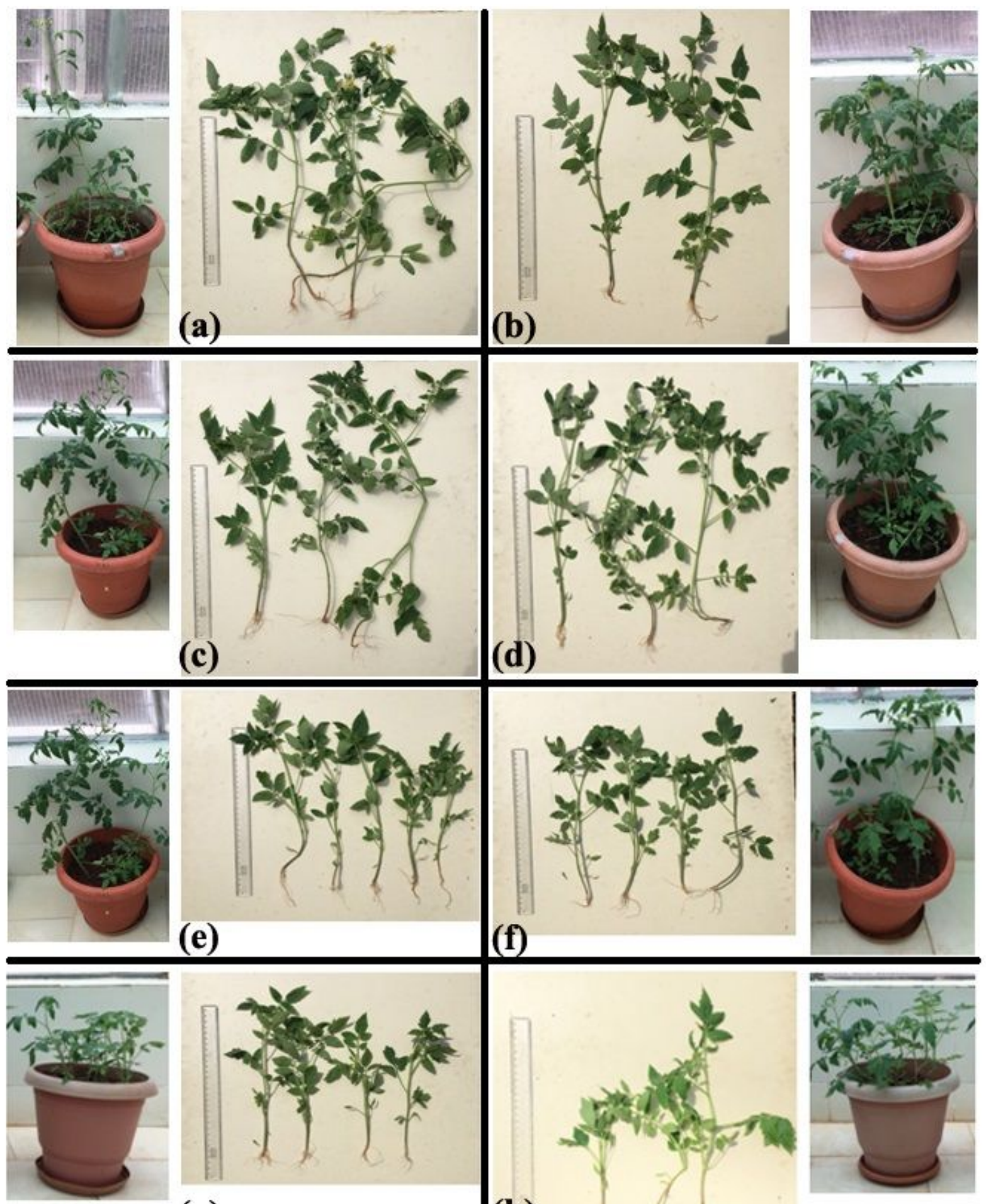

(g)

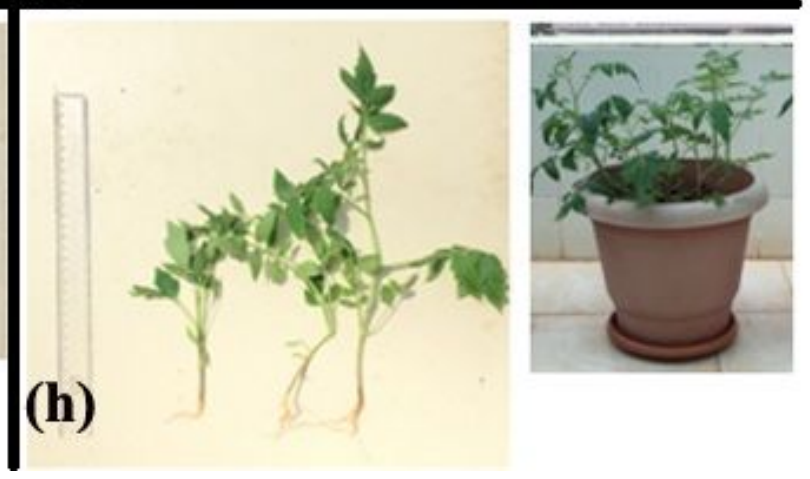

Figure 2

Pot culture experiments conducted to evaluate antifungal and plant growth promoting activity of Sg8 at climate controlled green house. 
a) Sg8 treated, b) Sg8 + FOC, c) SA treated, d) SA+FOC, e) BTH treated, f) BTH+FOC, g) FOC alone and h) Water control

(S. algae-Sg8, SA-Salicylic acid, BTH- Acibenzolar S Methyl)

\begin{tabular}{|c|c|c|c|c|c|c|c|c|c|}
\hline \multirow{10}{*}{ 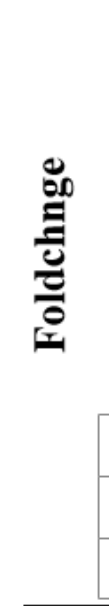 } & \multicolumn{4}{|c|}{ oth hr } & \multirow{10}{*}{ 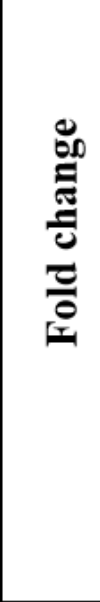 } & \multicolumn{4}{|c|}{ 48th hr } \\
\hline & \multirow{6}{*}{$\begin{array}{l}1.00 \\
0.80 \\
0.60 \\
0.40 \\
0.20 \\
0.00\end{array}$} & \multirow{6}{*}{$\operatorname{sg8}+F$} & \multirow[b]{6}{*}{$\mathbf{S A}+\mathbf{F}$} & \multirow[b]{6}{*}{$\mathbf{A c b}+\mathbf{F}$} & & \multirow{6}{*}{$\begin{array}{r}30.00 \\
\mathbf{2 5 . 0 0} \\
\mathbf{2 0 . 0 0} \\
15.00 \\
\mathbf{1 0 . 0 0} \\
\mathbf{5 . 0 0} \\
\mathbf{0 . 0 0}\end{array}$} & \multirow[b]{6}{*}{$\operatorname{sg} 8+F$} & \multirow[b]{5}{*}{$\square$} & \\
\hline & & & & & & & & & \\
\hline & & & & & & & & & \\
\hline & & & & & & & & & \\
\hline & & & & & & & & & \\
\hline & & & & & & & & \multirow{2}{*}{$\begin{array}{c}\text { SA+F } \\
0.53\end{array}$} & Acb $+F$ \\
\hline & PR1 & 0.05 & 0.02 & 0.02 & & PR1 & 0.72 & & 0.28 \\
\hline & PR2 & 0.01 & 0.00 & 0.00 & & — PR2 & 1.28 & 5.28 & 2.44 \\
\hline & PR5 & 0.02 & 0.77 & 0.02 & & PR5 & 0.55 & 2.02 & 27.03 \\
\hline \multirow{9}{*}{ 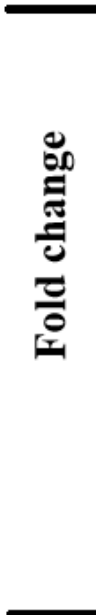 } & \multicolumn{4}{|c|}{ 6th hr } & \multirow{9}{*}{ 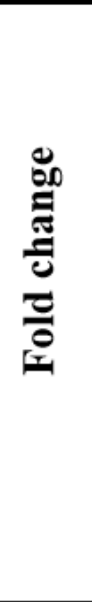 } & \multicolumn{4}{|c|}{ 7th day } \\
\hline & \multirow{5}{*}{$\begin{array}{r}20.00 \\
15.00 \\
10.00 \\
5.00 \\
0.00\end{array}$} & \multirow[b]{5}{*}{$\operatorname{sg} 8+F$} & & \multirow[b]{5}{*}{$\mathbf{A c b}+\mathbf{F}$} & & \multirow{5}{*}{\begin{tabular}{l|}
8.00 \\
6.00 \\
4.00 \\
2.00 \\
0.00
\end{tabular}} & & & \multirow{5}{*}{$\overline{A c b+F}$} \\
\hline & & & & & & & & & \\
\hline & & & & & & & & & \\
\hline & & & & & & & & & \\
\hline & & & & & & & sg8+F & $\mathbf{S A}+\mathbf{F}$ & \\
\hline & PR1 & 1.96 & 0.24 & 0.13 & & PR1 & 5.83 & 0.08 & 0.01 \\
\hline & PR2 & 17.34 & 0.30 & 0.07 & & PR2 & 6.87 & 0.84 & 0.13 \\
\hline & PR5 & 3.27 & 0.03 & 12.20 & & PR5 & 5.17 & 0.30 & 0.02 \\
\hline \multirow{9}{*}{ 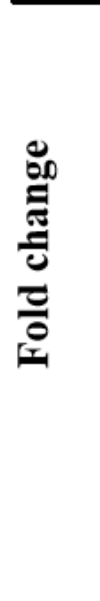 } & \multicolumn{4}{|c|}{ 24th hr } & \multirow{9}{*}{ 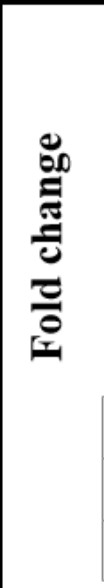 } & \multicolumn{4}{|c|}{ 14th day } \\
\hline & \multirow{5}{*}{$\begin{array}{r}20.00 \\
15.00 \\
10.00 \\
5.00 \\
0.00\end{array}$} & & & & & & & & \\
\hline & & & & & & $\begin{array}{l}2.50 \\
2.00\end{array}$ & & & \\
\hline & & & & & & $\begin{array}{l}1.50 \\
1.00\end{array}$ & & & \\
\hline & & & & & & $\begin{array}{l}0.50 \\
0.00\end{array}$ & & & \\
\hline & & $\operatorname{sg8}+F$ & $\mathbf{S A}+\mathbf{F}$ & $\mathbf{A c b}+\mathbf{F}$ & & & sg8+F & $\mathbf{S A}+\mathbf{F}$ & $\mathbf{A c b}+\mathbf{F}$ \\
\hline & PR1 & 0.84 & 2.39 & 0.15 & & PR1 & 1.46 & 2.47 & 0.01 \\
\hline & 口R2 & 0.61 & 9.29 & 1.58 & & 口R2 & 1.01 & 0.24 & 0.14 \\
\hline & PR5 & 0.34 & 0.84 & 17.24 & & PR5 & 1.12 & 0.34 & 0.31 \\
\hline
\end{tabular}

Figure 3

Pathogenesis related gene elicitation in tomato plants grown in soil infected with Fusarium oxysporum Supplementary Files 
This is a list of supplementary files associated with this preprint. Click to download.

- Supplementaryfiles.docx 